\title{
Holiness of life and dating practices of freshman and sophomore student at Adventist university of Indonesia
}

\author{
Stimson Hutagalung \\ Universitas Advent Indonesia, Jalan Kolonel Masturi no 288 Parompong, Bandung 40559, Indonesia \\ E-mail: Stimson_bern@yahoo.com
}

Copyright $\odot 2015$ Stimson Hutagalung. This is an open access article distributed under the Creative Commons Attribution License, which permits unrestricted use, distribution, and reproduction in any medium, provided the original work is properly cited.

\begin{abstract}
The purpose of this study is to determine the effect of holiness of life toward the practice of dating at University Advent Indonesia Bandung. The study covered aspects of holiness of life and practice of dating. The study was descriptive covering a simple random sampling of 84 respondents drawn from 541 students. Data collected through questionnaire and was analyzed using statistical tools SPSS 16. The practice of dating: holding hands when dating $36 \%$, hugging and kissing on the lips $10 \%$, heavy kissing $8 \%$, having sex $1 \%$. From data analysis concluded that the holiness of life affects only effected by $12.6 \%$ toward the practice of dating, while $87.4 \%$ influenced by other variables not examined, the value of the R Square below $5 \%$ or likely to approach a value of 0 , it can be concluded the ability of independent variables in explaining the variation of variables is very limited. This means that there was no effect between holiness of life toward dating practices.
\end{abstract}

Keywords: Holiness of Life; Dating Practice; Student.

\section{Introduction}

In the university environment, young people are very concerned with dating. Pham et al. [5] said that, "A romantic relationship is an important element in an adolescent life. Youth spend much of their time thinking, talking, and engaging in romantic relationships. Strong positive or negative emotions in youth are more commonly caused by romantic relationships as opposed to other kinds of relationships (such as with friends, parents, or school staff). Dating is a enjoyable activity.

During the period of dating, then many problems arise such as declining on Grade-Point Average, lot of absences in classes and pregnancy. According to Pham et.al. [5] Dating affected attitudes and behaviours on gender. Women became more passive than man. Gisip et al [3] found that dating will lower the index of Student Achievement; Stephanou found that dating has an influence on achievement of student in the classroom. [8].

More specific, Josh McDowell and Bob Hostetler in their book Right from Wrong quoted Barna Research about dating bahaviour to 3.795 young people from 13 denominations like the Christian church. The result of the research are that young children have been dating since the age of 11 years and has been doing of dating behavior that does not conform to religious norms, $27 \%$ of 17 years-old young people have sexual intercourse. [4] The data is shown by the table 1.1 below.

Table 1: Sexual Activity with the Opposite Kind, by Age Group.

\begin{tabular}{|c|c|c|c|c|}
\hline Activities & Age: $11-12$ & Age: $13-14$ & Age: $15-16$ & Age:17-18 \\
\hline Holding hand & $74 \%$ & $84 \%$ & $92 \%$ & $95 \%$ \\
\hline Hug and kiss & $39 \%$ & $65 \%$ & $80 \%$ & $86 \%$ \\
\hline French kiss & $15 \%$ & $38 \%$ & $61 \%$ & $74 \%$ \\
\hline Breast playing & $4 \%$ & $20 \%$ & $41 \%$ & $55 \%$ \\
\hline Pubic playing & $2 \%$ & $14 \%$ & $30 \%$ & $44 \%$ \\
\hline Sexual intercourse & $1 \%$ & $8 \%$ & $18 \%$ & $27 \%$ \\
\hline
\end{tabular}


Viewed from above results it can be concluded that dating behavior among young people have come to critical points that required to be concerned by parents, educators and the church members. They must increase their role in order to overcome the negative impact of dating.

Adventist University of Indonesia is a bording university inhabited by male and female students. Besides studying at this campus, they are also equipped with a spiritual activity every day. As time goes by, not infrequently between male and female students are attracted to each other, and finally they were dating. Based on the observations and supported by data from the department of guidance and counseling found that there are some couples who had to go to the disciplinary committee meeting because they were caught in the act of lips kissing while dating, even some of them pregnant and had to get out from the campus.

Based on observations, derived data and previous studies, the reseracher interested in study about young people dating from a different angle, namely to discuss the specifics of holiness of life that has been applied and its effect on the practice of student dating at Adventist University of Indonesia, Bandung.

The connection between holiness of life and dating practices are proposed in the following hypotheses:

$\mathrm{H} 0: \mathrm{r}=0$ There is no effect between holiness of life toward dating practices of student at Adventist University of Indonesia.

Ha: $r<0$ there is an effect between holiness of life toward dating practice of student at Adventist University of Indonesia.

\section{Theoretical review}

Principal of holiness of life become one important part in social life. Because God is holy, He wants His people also to become holy. The meaning of the holiness of life waned along with the times today. Standard holiness of life has been compromised by lowering the standard of the Bible as a rule of absolute truth with postmodern world living standards, whereas, firmly White [11] wrote that "Holiness of heart and holiness of life are the most important subjects given by God to mankind, which is the crown of His creation. After Jesus gave the gist of what to do and what not to do in this life in his famous sermon is the sermon on the Mount, Jesus said in Matthew 5: 48: "Be ye. Therefore, perfect, even as your Father who is in heaven is perfect. "Perfection God closely associated with His holiness." As God's holy presence of God in the environment, so man should be sacred for the human environment. Holiness inherent in to character of God, that is why all who come and draw near to God must be first holy.

\subsection{Leaving in holiness}

Being holy is one of the commands in the Bible. Become holy in the Greek language is hagiasmos means holiness, surrender, consecration; hagaios means to make holy, deliver, sanctify, alienating. The word "holy" or "holiness" in the form of an adjective, noun, and verb-contained 275 times in the New Testament. The definition of modern theology of purification described through the character development process. As used in the New Testament "sanctification" and "justification" has the same sense that the change of status of sinfulness to holiness and subsequently of unrighteousness unto justification. As such, being holy is the change in character must first undergo a process leading into the recovery picture / image and likeness of God that has been lost due to sin.

\subsection{His name is holy}

The name of God is holy because it expressed His nature. Creator and Ruler of the universe of this nature in perfection, power and glory is a holy God above all things. Wherever God is present the place become a holy place, "For where two or three are gathered together in my name, there am I in the midst of them." Matt. 18:20. The place where people gather and call His name earnestly, then His promise is definitely present, the consequence is the place will be holy and respect must be shown on the spot to the Owner's name, included in the hearts of men will be holy when the Holy One enthroned there.

\subsection{Imago Dei}

God created man in the image and likeness of God and the Bible also describes God using human organs. "The Bible says of God in human terms, that God has form (Exodus 20:14; Numbers 12: 8) with feet (Genesis 3: 8; Exodus 24:10), hand (Ex. 24:11), mouth (Numbers 12: 8; Jeremiah 7:13) and liver (Hosea 11:8).

Definition the word created in the image and likeness of God described by Brotosudarmo [1] as follows, "The essence of our humanity is the image of God (Gen. 1: 26-27). Likeness of God that includes the image of God (imago Dei) and God's example (similitudo Dei). Completeness is God-given to humans to perform tasks that have been given by Him. "Created in His image is a very important point, which makes human, different from other creatures and called as the crown of God's creation. 


\subsection{Similitudo Dei}

At the time of Adam and Eve were created not only about similarity with the image of God but also reflects God's character. Struthers [9] explained the words "Let us make man in our image," the Hebrew word means "demut" translated as similitudo in Latin and likeness (form) in English. Broto Sudarmo gave meaning of Similitudo Dei as follows. Similitudo Dei means God's example; demut means similarity (inner side), ie, one talent, one character, one character. "It states that the actual nature of His holy even then revealed His creation namely mankind.

\section{Reflecting the mind of god}

God gave human brain with the power to think. The bible gives the following explanation about mind, "in the Old Testament; the term heart (leb) means the total nature combines with emotion, will and intellectual of men and women. It has a combined meaning called 'mind' (Deuteronomy 15: 9; Judges 5: 16-16) or 'reason' (Job 8:10; 12: 3; 34; 10) and is often used with the idea of thought or someone desires. In this sense, what is "in heart'" actually means "what is in the mind" and what is in the minds of women and men to make them as they exist. "But as a thought in his heart, so is he." (Proverbs 23: 7). "At the time of the creation of Adam and Eve in the mind of God bestowed the power to think that great and holy as the Garden of Eden's neighborhood in enclosed holiness of God.

\subsection{Dating}

Dating is a recognition that a person getting to know one another before they decide whether to proceed to a more serious relationship, namely engagement even to the marriage. When they have a relationship then they will face many principles differences then they decided to end the dating relationship. Susabda [10] provides an explanation about dating that "dating for Christians is a time for two personal specifically knowing each other with the purpose of marriage. Specifically not means the introductory period but knowing each other, specifically. [10]

There are two models of dating, the first model is "modern dating, the focus of modern dating is finding partner only to meet all the needs and desire of couples. The second model of dating is called biblical dating which focus in finding a suitable spouse. The first model of dating is dating with lust, prefers for momentary pleasure, prioritizing intimacy rather than a commitment. The second model of dating is to find partner and to see matches or differences from each couple, if there is a difference let those differences make the couple committed to accept each other and support each other as they are [7]

According to a survey conducted by Dowell [4], there are six of dating behaviors which is conducted by young people according to the degree of physical contact as described in Table 1.2 below.

Table 2: Dating Behavior of Young People

\begin{tabular}{lllll}
\hline & Activities & Done & Not Done & Not Sure \\
\hline A & Holding hand & $89 \%$ & $10 \%$ & $1 \%$ \\
B & Hug and kiss & $73 \%$ & $25 \%$ & $2 \%$ \\
C & French kiss & $53 \%$ & $45 \%$ & $2 \%$ \\
D & Breast playing & $34 \%$ & $63 \%$ & $3 \%$ \\
E & Genital playing & $26 \%$ & $71 \%$ & $3 \%$ \\
F & Sexual intercourse & $16 \%$ & $81 \%$ & $3 \%$ \\
\hline
\end{tabular}

From the above table can be concluded that the behavior of of dating that have been done by young people already go beyond the normal limits of dating activities. Therefore, researcher used Dowell indicators as indicator in this research.

\section{Research methodology}

Research population are freshman and sophomore student at the Adventist University of Indonesia, Bandung, with total of 541 students. The samples in this study using simple random sampling, with Taro Yamane formula [6] that is 84 student. $60 \%$ aged $18-20$ and $40 \%$ aged $21-23$ years. $51 \%$ have been dating for less than a year; $20 \%$ had been dating from two years; $11 \%$ have been dating for three years, and $18 \%$ have been dating for more than three years. The research instrument used was questionnaire, analysis of data using simple regression analysis.

\section{Result}

Prior to the data analysis researcher have done a validation test and reliability test and all data declared valid and reliable so that the data deserves to be analyzed. 


\subsection{Descriptive Analysis}

1) Holiness of life based on understanding: His name is Holy.

The understanding of student about holiness of life based on the name of God is holy, 95\% respondents are in the category of very agreed and agreed means students understood that the name of God is holy, so they know how to maintain dating behavior in the corridors of holiness, but there are students who do not understand about the name God is holy with a total of $5 \%$.

2) Holiness of life based on understanding: Human should reflecting image of God

The understanding of student about holiness of life based on human should reflecting image of God, 96\% respondent are in the category of very agreed and agreed means students understood that as a good Christian they should reflecting God's image in everything they do exspecially while dating this means they know how to maintain dating behavior in the corridors of holiness, but there are students who do not understand about reflecting God's image with total of $4 \%$.

3) Holiness of life based on understanding: Human should reflecting visual of God

The understanding of student about holiness of life based on human should be reflecting visual of God, 93\% respondent are in the category of very agreed and agreed means students understood that as a good Christian, they should be reflecting the visual of God on their own body this means they know how to protect their body in corridors of holiness while dating, but there are students who do not understand about reflecting the visual of God on their own body as a total of $7 \%$.

4) Holiness of life based on understanding: Human should reflecting the mind of God

The understanding of student about holiness of life based on human should reflecting the mind of God, 87\% respondent are in the category of very agreed and agreed means students understood that as a good Christian they should reflecting the mind of God this means that the way they are thinking while dating are in corridors of holiness but there are students who do not understand about reflecting the mind of God with total of $13 \%$.

The details about percentage of each indicators shown in table 1.3 below.

Table 3: Summary of Questionnary Results Holiness of Life

\begin{tabular}{|c|c|c|c|c|c|c|}
\hline NO & Statements & Very agreed & Agreed & Neutral & Seldom & Never \\
\hline 1 & His name is Holy & $60 \%$ & $35 \%$ & $4 \%$ & $1 \%$ & 0 \\
\hline 2 & Human should reflecting image of God & $84 \%$ & $12 \%$ & $2 \%$ & $2 \%$ & 0 \\
\hline 3 & Human should reflecting visual of God & $56 \%$ & $37 \%$ & $5 \%$ & $2 \%$ & 0 \\
\hline 4 & Human should reflecting the mind of God & $33 \%$ & $54 \%$ & $12 \%$ & $1 \%$ & 0 \\
\hline
\end{tabular}

5) Dating Practice: Holding hand

Dating practice "holding hand", $36 \%$ of the respondent did it while dating, $64 \%$ respondent seldom did it. This indicates that dating activity of the student is still at normal corridor.

6) Dating Practice: Hug and kiss

Dating practice "hug and kiss", $28 \%$ of the respondent did it while dating, $26 \%$ seldom did it and $46 \%$ of the respondent never did. This indicates that even $46 \%$ respondent never hugging and kissing while dating, but there are $52 \%$ respondent did it in often and seldom category.

7) Dating Practice: French kiss

Dating practice "French kiss", 21\% of the respondent did it while dating, 15\% seldom did it and 64\% of the respondent never did. This indicates majority $64 \%$ respondent never do French kissing, but there are $36 \%$ respondent did it in often and seldom category.

8) Dating Practice: Genital Playing

Dating practice "Genital Playing", $8 \%$ of the respondent did it while dating, $8 \%$ seldom did it and $84 \%$ of the respondent never did. This indicates majority of $84 \%$ respondent never do genital playing, but there are still $16 \%$ respondent did it in often and seldom category.

9) Dating Practice: Sexual Intercourse

Dating practice "Sexual Intercourse", 4\% of the respondent did it while dating, 6\% seldom did it and $90 \%$ of the respondent never did. This indicates majority of $90 \%$ respondent never do intercourse, but there are still $10 \%$ respondent did it in often and seldom category.

The details about percentage of each indicators shown at table 1.4

Table 4: Summary of Questionnary Results Dating Practices

\begin{tabular}{lllllll}
\hline NO & Statements & Very agreed & Agreed & Neutral & Seldom & Never \\
\hline 1 & Holding hand & $10 \%$ & $26 \%$ & $31 \%$ & $21 \%$ & $12 \%$ \\
2 & Hug and Kiss & $6 \%$ & $4 \%$ & $18 \%$ & $26 \%$ & $46 \%$ \\
3 & French Kiss & $4 \%$ & $4 \%$ & $13 \%$ & $15 \%$ & $64 \%$ \\
4 & Genital Playing & $2 \%$ & $1 \%$ & $5 \%$ & $8 \%$ & $84 \%$ \\
5 & Sexual Intercourse & $1 \%$ & $0 \%$ & $3 \%$ & $6 \%$ & $90 \%$ \\
\hline
\end{tabular}




\subsection{T-test}

T test used to find out whether the independent variables partially influence or no influence on the dependent variable. The degree of significance used was 0.05 . If the value is significantly smaller than the degree of confidence then we accept the alternative hypothesis, which states that a partially independent variables affect the dependent variable.

Table 5: Table Model Koefisien

\begin{tabular}{lll}
\hline Model & $\mathrm{t}$ & Sig \\
\hline 1. (Constant) & 7.550 & .000 \\
TX & 1.154 & .252 \\
\hline
\end{tabular}

(The data has been processed from SPSS 16)

Viewed from the column coefficients found that sig is 0.252 . Sig value is greater than the probability value of 0.05 , or $0.252<0.05$, then Ho accepted and Ha rejected. T-count is 1,154 with $\mathrm{t}$-table $=2,021$. So t-count $<\mathrm{t}$ table it can be concluded that the variable X (Dating Practices) has no contribution to Y (holiness of life). The value of $t$ is positive (1, 154) indicates that variable $X$ has a direct relationship with the $Y$. So we can conclude the holiness of life does not significantly influence the dating practices.

\subsection{Coefficient of determination}

The coefficient of determination in linear regression is often defined as how much ability of all independent variables in explaining the variance of the dependent variable. In a simple coefficient of determination is calculated by squaring the correlation coefficient (R).

In this study, it can be concluded that, Holiness of life influenced only by $12.6 \%$ toward dating practices, while $87.4 \%$ is influenced by other variables not examined. Because the value of R Square below $5 \%$ or tends to approach the value 0 , it can be concluded capability independent variables in explaining the variation of variables is very limited.

The details outlined in table 1.6 below.

Table 6: Table Model Summary

\begin{tabular}{llll}
\hline Model & R & Adjusted R Square & Std. Error of the Estimate \\
\hline 1 & .126 & .004 & 4.43328 \\
\hline $\begin{array}{l}\text { a. Predictors: (Constant), TX } \\
\text { (The data has been processed from SPSS 16) }\end{array}$
\end{tabular}

\section{Conclusion}

1) From descriptive data, can be concluded that $40.8 \%$ of students while dating did touch each other ranging from mild to severe, and $10 \%$ of them had intercourse. Guidance and attention should be given to the students in their dating behavior. Church pastor and Elders, Counselor, Campus Ministry and leaders in institution should take immediate action to save the students who will become the next generation of this church from wrong dating practices.

2) From the data analysis found out that there is no effect between the holiness of life toward dating practices.

\section{Discussion}

The result from descriptive data found out that dating a little amount of student have acted beyond the limits of reasonableness dating like kissing until sexual intercourse. Researcher assume that students in UNAI has represented Adventist young people in Indonesia, because these students came from a variety of places ranging from Sumatra to Papua. The question is how can negative dating practices while dating can be prevented?

\section{Recommendations}

Based on the above results, the researcher give some suggestions:

1) In dating activities students should have boundaries or reasonable limitation dating activities. Cloud and Townsend [2] said that "Dating involves risk and therefore, creates boundaries to help pass those risks safely. The boundary line will protect young people who are dating. Learn to appreciate the boundaries, such as control your emotions, behaviors and attitudes. A clear boundary line will help young people to have good quality of dating, because they will help each other become better people." This principle should be induced to all young people who are dating or who will be dating. 
2) Pastors, church elders, staff and faculty of UNAI should be a role model, as parents of the students and also to provide guidance, advice and monitoring through:

- Small groups conducted in houses of staff and faculty doing worship together; discuss the matter concerning dating, relationships and problems of young people. Can be organized every month to create closeness between faculty and staff.

- $\quad$ Conducting seminars and sermons in churches regularly to be discussed about youth problem, including dating.

- $\quad$ Empowering guidance and Counseling department to be more active in campaigning for dating behaviors that promote Christian values in accordance with the Bible and provide counseling for young children.

Forming mentoring group among students train and equip them so they can help each other (among friends).

\section{References}

[1] Brotosudarmo, R.M. Drie S. (2007). Etika Kristen untuk Perguruan Tinggi. Yogyakarta: Andi Offset. Page 45

[2] Cloud.Henry dan John Townsend. (2004).Membangun Hubungan Cinta yang Berhasil, Batas-Batas dalam Kencan dan Pacaran, Batam: Interaksara. Page 76

[3] Gisip, Imelda Albert, Ddwayan, Cynthia, David, Jasmin. (2011). Effects of Romantic Relationships to Academic Performance. Thesis. Page 52.

[4] McDowell, Josh dan Bob Mostetler. (1997). Right From Wrong (Antara Benar Dan Salah), Jakarta: Professional Books. Pages 4, 31,301.

[5] Pham, Chung Pham, Keenan. Tracy Keenan, Hang, Bing. (2013). Evaluating Impacts of Early Adolescent Romance in High School on Academic Outcomes.Journal of Applied Economics and Business Research JAEBR. Page 14.

[6] Riduwan, Metode dan Teknik Menyusun Tesis.,( 2006). Bandung: Alfabeta. Page 54

[7] Saptaji Arie, Pacaran Asyik Dan Cerdas. (2010). Yogyakarta: Gloria Graffa. Page 100.

[8] Stephanou, Georgia. (2012). Romantic Relationships in Emerging Adulthood: Perception-Partner Ideal Discrepancies, Attributions, and Expectations.Journal Psychology. Page 15. http://dx.doi.org/10.4236/psych.2012.32023.

[9] Struthers, William M. (2012). Wired For Intimacy Bagaimana Pornografi membajak Otak Pria, Surabaya: Literatur Perkantas Jawa Timur. Page 8.

[10] Susabda, B, Yakub. (2003). Pastoral Konseling II, Malang:Penerbit Gandum Mas. Page 111.

[11] White G. Ellen. (1991). Rumah Tangga Advent, Bandung: Indonesia Publishing House. Page 17. 